\title{
EFFECT OF TWO GIRDLING DATES ON CARBOHYDRATE ACCUMULATION IN PLANT TISSUES AND FRUIT QUALITY OF BARBERRY
}

\author{
Mina MOQHADDAM*, Zeinab AREFNEZHAD, Mehdi KHAYYAT \\ University of Birjand, Iran
}

Received: April 2018; Accepted: February 2019

\begin{abstract}
The present study was designed to investigate the effects of two girdling dates (late April and early September) on fruit quality and carbohydrate accumulation in barberry shrubs (Berberis vulgaris L.) during the years 2016-2017. One year old shoots were ringed and fruit characteristics were monitored for two continues year. Data showed that the girdling caused a significant increase in the ascorbic acid content in fruit. Similarly, anthocyanin and total acidity were affected by girdling compared to control in 2017. September-girdled shrubs had the highest amount of fresh mass but the dry mass was not changed. It was shown that chlorophyll $b$ increased in the girdled shrubs compared to control. September girdling reduced the carbohydrate content in leaves. In contrast, it increased the carbohydrate content in shoots. In addition, there was a significant difference between starch in the shoot and starch in leaf. Owing to the obtained results, early September girdling caused a broad range on fruit quality.
\end{abstract}

Keywords: starch, chlorophyll, anthocyanin, ringing, seedless barberry

\section{INTRODUCTION}

Seedless barberry (Berberis vulgaris L.), belongs to the Berberidaceae family that grows in the mountainous north-east of Iran, Khorasan (FatehiHassanabad et al. 2005). Barberry is one of the plants that contain berberine and has had a long history in eastern and western medical tradition (Chevallier 2001), and it is still used in northern Europe (Fatehi-Hassanabad et al. 2005). Bark, root, rhizomes, stem, leaf, and fruit are used in medicine (Arayne et al. 2007).

The removal of a ring of phloem (girdling, ringing) is a horticultural practice that results in an accumulation of carbohydrates and used to influence tree growth and development and fruit growth, especially in citrus, grape, peach, and other fruit tree crops (Roper \& Williams 1989; Schaper \& Chacko Csiro 1993; Goren et al. 2004). According to the result of some preliminary experiments, the timing of treatment is important (Noel 1970; Priestley 1976).
Ringing interrupts the phloem pathway and consequently change the pattern of distribution (Mason \& Maskell 1928). By girdling, the flow of sap stops, carbohydrates and starch accumulate above the girdle, and also in production and translocation of certain plant hormones are arrested (Davie et al. 1995). Moreover, it influences the metabolic activity of shrubs, primarily by increasing carbohydrate accumulation above the girdle and reducing the sink strength for photosynthate below the girdle (Martin et al. 1994; Nordgren et al. 2003). In addition, reduction in stomatal conductance (gs) and increase in leaf water potential have been observed in girdled shrubs (Williams et al. 2000). Trunk girdling is one of the many options to control excessive shoot growth and to accelerate fruit maturation.

Girdling has been widely used in many fruit tree crops, mainly to increase flowering, fruit set and fruit size (Goren et al. 2004). Horticultural effects of girdling are a lot. As example, all stages of reproductive organs, development, flowering, fruit 
set and in many instances fruit maturity and quality are influenced by girdling. However, the mechanism(s) through which girdling operates are not yet fully understood (Janick 2003). Khandaker et al. (2011) reported that ringing could improve yields and physical and chemical properties of fruit. Zhao et al. (2013) reported that girdling in mid-May increased ascorbic acid and decreased titratable acid in apple. It has been reported that ringing increased total phenolic content in peach fruit (Kubota et al. 1993) and increased the level of anthocyanin in the berry skin of crimson seedless grapes (Brar et al. 2008). In citrus, girdling a few weeks before flowering increased leaf chlorophyll content and carbohydrate concentration in various flowering and vegetative shoots (Rivas et al. 2008). Girdling date did not significantly affect fresh mass in persimmon (Choi et al. 2010). Delayed maturation of the fruit manifesting in the late change of color to red late fruit-color change in barberry and also low fruit quality are the most important problems related to barberry. So, the aim of this study was to investigate the effect of two girdling dates on the accumulation of anthocyanin and the quality of fruit in barberry.

\section{MATERIAL AND METHODS}

This study was conducted in the research orchard of the Faculty of Agriculture, University of Birjand (Iran) in 2016-2017. Similar 50 year-old shrubs were spaced $3 \mathrm{~m}$ in rows and $3 \mathrm{~m}$ between rows were selected as plant materials. The 45 oneyear-old shoots with the same length $(45 \pm 5 \mathrm{~cm})$, diameter, and productivity were tagged for future treatments. On each shrub, three shoots were chosen. The 2-mm width ringing was performed in late April and early September at the base of each shoot. Generally, ringing was performed on same shrubs in 2016 and 2017. Fruits were harvested on mid-October and separately juiced for chemical measurements by hand.

Ascorbic acid content was determined by indophenol method, and the value was expressed as milligram of ascorbic acid per $100 \mathrm{ml}$ of juice (Ranganna 1977).

The total anthocyanin content of juice was determined by the $\mathrm{pH}$-differential method using two buffer systems consisted of potassium chloride $(\mathrm{pH} 1,0.025 \mathrm{M})$ and sodium acetate $(\mathrm{pH} 4.5$, $0.4 \mathrm{M}$ ). One milliliter of juice sample was mixed with $10 \mathrm{~mL}$ of buffer, and the absorbance (A) was measured at 510 and $700 \mathrm{~nm}$ using a Unico 2100 spectrophotometer (Wagner 1979).

Total acidity (TA) was determined by titration of $1 \mathrm{ml}$ of juice with $0.2 \mathrm{M}$ of $\mathrm{NaOH}$, and the results were calculated as a percentage of citric acid (Cochran et al. 1986).

The total phenolics of juice was determined by Folin-Ciocalteu method at a wavelength of $725 \mathrm{~nm}$ and expressed as a percentage of gallic acid (Chuah et al. 2008).

Chlorophylls in leaves were determined in May, June, and October. About $0.025 \mathrm{~g}$ of leaves was homogenized in $5 \mathrm{ml}$ of $80 \%$ acetone. The samples were stored for $24 \mathrm{~h}$ in a fridge, and then the absorbance was read at 470,645, and $663 \mathrm{~nm}$ by Unico 2100 spectrophotometer (Lichtenthaler 1987).

Fresh mass of 100 berries was measured. To determine the dry mass, 100 berries were oven dried at $70{ }^{\circ} \mathrm{C}$ for $72 \mathrm{~h}$ and dry mass was recorded.

Shoots and leaves samples were taken from the shrubs at late-May and late-October. Shoots and leaves were separately oven dried at $50{ }^{\circ} \mathrm{C}$ for $70 \mathrm{~h}$ to determine total carbohydrate. Total carbohydrate was determined according to the anthrone method by Unico 2100 spectrophotometer (Mocready et al. 1950) and the starch amount was determined using colorimetric method (Magel 1991).

The trial was conducted as completely randomized block design with three treatments and five replications. In each replication, 3 shoots were chosen for sampling. The treatments included were (1) control shrubs (the non-girdled shoots), (2) girdled shoots in late April, and (3) girdled shoots in early September. Obtained data were analyzed by Genstat Ninth Edition, and mean values were compared at the level of 5\% according to LSD test. Obtained results in 2016 and 2017 were analyzed separately.

\section{RESULTS AND DISCUSSION}

Fresh mass was not significantly affected by girdling (2016) (Table 1). September girdling had 
the highest fresh mass (38.2 g) in 2017 and the lowest $(16.1 \mathrm{~g})$ in 2016 by control treatment.

Fruit mass is an important quality parameter of fruit production. Bark ringing or girdling significantly increased the fruit mass as well as yield (Sharif et al. 2007). Girdling can improve carbohydrate availability to fruits and as a consequent lead to an increase in fruit-set and yield as well as a number of fruits (Goren et al. 2004; Rivas et al. 2004). Our results are in agreement with the findings of Mostafa \& Saleh. (2006), who reported that girdling increased the fruit mass in balady mandarin orange. Dry mass was not significantly affected by girdling in 2017.

Generally, girdling significantly increased the ascorbic acid content in fruits (Table 1). The highest ascorbic acid content was obtained in the second girdling in September 2016. In the following year (2017), both girdling dates (April and September) significantly increased the ascorbic acid content in fruits. The effect of girdling time on ascorbic acid was significant in 2017. Cultural practices such as girdling determine the crop load and fruit size, which can influence the nutritional composition of fruits (especially nitrogen) and may indirectly affect the vitamin C content (Lee \& Kader 2000). Zhao et al. (2013) stated that vitamin $C$ content in apple increased with girdling.

In the first year, anthocyanin was not affected by girdling, but both April and September girdling significantly increased anthocyanin content in the second year. The lowest anthocyanin content $\left(69 \mathrm{mg} \cdot \mathrm{dm}^{-3}\right)$ was observed in September 2016
(Table 1). Anthocyanin pigments are responsible for the red, purple, and blue colors of many fruits and also they have possible health benefits as dietary antioxidants (Ronald \& Wrolstad 2001). Girdling accelerated ripening and also had positive effects on anthocyanin accumulation in the fruits (Khandaker et al. 2011). Accumulation of anthocyanin was also reported in girdled grape by El-Hammady and Abd-ElHamid (1995). Girdling increased significantly TA compared with control in 2017 (Table 1).

It was reported that girdling of Italia grape at the beginning of ripening significantly reduced titratable acidity (Carreño et al. 1998). However, the opposite response was found with girdling in apple (Arakawa et al. 1998).

Content of total phenolics in fruits with average value of 64.5 was not influenced by girdling (Table 1) that was disagreement with the result obtained in peach (Kubota et al. 1993).

There were no significant differences in chlorophyll a content among different sampling time. The lowest amount of chlorophyll $b$ (4.59) and the ratio of chlorophyll $b$ to chlorophyll a (0.306) were observed in control.

The effect of girdling was significant on chlorophyll a content, chlorophyll b content, and the ratio of chlorophyll $b$ to chlorophyll a contents. Girdling in April did not increase the chlorophyll a and chlorophyll $b$. The amount of chlorophyll a content, chlorophyll $b$ content, and the ratio of chlorophyll $b$ to chlorophyll a ratio were highest in September girdling when compared to those observed for the first time in April (Table 2).

Table 1. The effect of girdling on fruit characteristics of barberry separately for each year of investigation

\begin{tabular}{|c|c|c|c|c|c|c|}
\hline Girdling date & $\begin{array}{l}\text { F.m. of } 100 \\
\text { berries }(\mathrm{g})\end{array}$ & $\begin{array}{l}\text { D.m. of } \\
100 \text { berries } \\
(\mathrm{g})\end{array}$ & $\begin{array}{l}\text { Ascorbic acid } \\
\left(\mathrm{mg} \cdot 100 \mathrm{ml}^{-1}\right)\end{array}$ & $\begin{array}{l}\text { Anthocyanin } \\
\left(\mathrm{mg} \cdot \mathrm{dm}^{-3}\right)\end{array}$ & $\begin{array}{l}\text { Total acidity } \\
\left(\mathrm{g} \cdot 100 \mathrm{ml}^{-1}\right)\end{array}$ & $\begin{array}{l}\text { Total phenolics } \\
\quad(\mathrm{mg} \text { gallic } \\
\left.\text { acid } \cdot \mathrm{g}^{-1} \mathrm{DM}\right)\end{array}$ \\
\hline \multicolumn{7}{|c|}{2016} \\
\hline Control & $16.1 \mathrm{a} \pm 3.4$ & - & $1500 b \pm 623$ & $145 a \pm 36.5$ & $55.4 \mathrm{a} \pm 11.9$ & - \\
\hline April girdling & $16.8 \mathrm{a} \pm 3.1$ & - & $1500 b \pm 661$ & $142 \mathrm{a} \pm 31.2$ & $39.3 a \pm 15.4$ & - \\
\hline September girdling & $19.1 \mathrm{a} \pm 3.2$ & - & $2167 a \pm 597$ & $169 a \pm 29.8$ & $46.5 \mathrm{a} \pm 15.1$ & - \\
\hline \multicolumn{7}{|c|}{2017} \\
\hline Control & $24.5 c \pm 4.2$ & $3.6 \mathrm{a} \pm 0.7$ & $840 c \pm 353.5$ & $81 b \pm 134.0$ & $32.0 \mathrm{c} \pm 8.1$ & $64.7 \mathrm{a} \pm 0.007$ \\
\hline April girdling & $33.8 b \pm 1.2$ & $4.1 \mathrm{a} \pm 0.3$ & $1119 \mathrm{a} \pm 353.5$ & $122 \mathrm{a} \pm 31.1$ & $41.5 \mathrm{a} \pm 11.1$ & $64.5 \mathrm{a} \pm 0.003$ \\
\hline September girdling & $38.2 \mathrm{a} \pm 0.8$ & $4.5 \mathrm{a} \pm 1.0$ & $1095 b \pm 204.1$ & $124 a \pm 26.6$ & $39.1 b \pm 12.1$ & $64.4 \mathrm{a} \pm 0.0006$ \\
\hline
\end{tabular}

In each column, separately for year of investigation, means with the same letter are not significantly different at $5 \%$ level of probability using LSD 
Table 2. The effect of girdling and sampling time on leaves chlorophyll of barberry (2017)

\begin{tabular}{|c|c|c|c|c|}
\hline Effect & & Chl a $\left(\mu \mathrm{g} \cdot \mathrm{cm}^{-3}\right)$ & Chl b $\left(\mu \mathrm{g} \cdot \mathrm{cm}^{-3}\right)$ & Chl b/Chl a \\
\hline & \multicolumn{4}{|c|}{ Sampling Time } \\
\hline May & & $14.0 \mathrm{a} \pm 0.6$ & $4.6 b \pm 0.8$ & $0.31 \mathrm{c} \pm 0.05$ \\
\hline June & & $13.1 \mathrm{a} \pm 1.02$ & $5.0 \mathrm{a} \pm 0.5$ & $0.38 b \pm 0.02$ \\
\hline October & & $13.8 \mathrm{a} \pm 0.9$ & $6.0 \mathrm{a} \pm 0.3$ & $0.44 \mathrm{a} \pm 0.01$ \\
\hline \multicolumn{5}{|l|}{ Treatment } \\
\hline Control & & $14.3 \mathrm{a} \pm 0.7$ & $5.6 \mathrm{~b} \pm 0.4$ & $0.39 \mathrm{a} \pm 0.01$ \\
\hline April girdling & & $10.7 b \pm 0.6$ & $3.0 \mathrm{c} \pm 0.6$ & $0.29 b \pm 0.05$ \\
\hline September girdling & & $15.8 \mathrm{a} \pm 0.5$ & $7.0 \mathrm{a} \pm 0.2$ & $0.44 \mathrm{a} \pm 0.0007$ \\
\hline Treatment & \multicolumn{4}{|c|}{ Sampling time } \\
\hline \multirow{3}{*}{ Control } & May & $14.24 \mathrm{a} \pm 0.7$ & $6.0 \mathrm{a} \pm 1.0$ & $0.42 \mathrm{a} \pm 0.04$ \\
\hline & June & $13.75 \mathrm{a} \pm 1.7$ & $4.5 b \pm 0.1$ & $0.34 b \pm 0.03$ \\
\hline & October & $14.95 \mathrm{a} \pm 1.8$ & $6.3 \mathrm{a} \pm 0.6$ & $0.42 \mathrm{a} \pm 0.01$ \\
\hline \multirow{3}{*}{ April girdling } & May & $11.86 \mathrm{a} \pm 0.5$ & $0.8 \mathrm{c} \pm 0.8$ & $0.06 \mathrm{c} \pm 0.06$ \\
\hline & June & $9.70 \mathrm{a} \pm 1.6$ & $3.7 \mathrm{~b} \pm 1.1$ & $0.35 \mathrm{a} \pm 0.06$ \\
\hline & October & $10.63 a \pm 0.9$ & $4.7 b \pm 0.5$ & $0.45 \mathrm{a} \pm 0.03$ \\
\hline \multirow{3}{*}{ September girdling } & May & $15.79 \mathrm{a} \pm 1.1$ & $7.0 \mathrm{a} \pm 0.4$ & $0.44 \mathrm{a} \pm 0.001$ \\
\hline & June & $15.79 \mathrm{a} \pm 1.1$ & $7.0 \mathrm{a} \pm 0.4$ & $0.44 \mathrm{a} \pm 0.001$ \\
\hline & October & $15.79 \mathrm{a} \pm 1.1$ & $7.0 \mathrm{a} \pm 0.4$ & $0.44 \mathrm{a} \pm 0.001$ \\
\hline
\end{tabular}

In each column means with the same letter are not significantly different at 5\% level of probability using LSD

Accordingly, in our study, girdling increased the leaf chlorophyll b content in both the years. Several authors have proposed that total leaf carbohydrate content and starch increased as a result of girdling (Rivas et al. 2008). It may be due to the accumulation of chlorophyll content and increased photosynthesis in the girdled branch (Khandaker et al. 2011).

The highest amount of chlorophyll $b$ was recorded in second girdling treatment on three sampling time, whereas the lowest amount was obtained during the first girdling. The ratio of chlorophyll a to chlorophyll $b$ was not significantly different from other treatments during the sampling, but the lowest value was observed in the control and second girdling on second and third sampling time (Table 2).

Total carbohydrate content in leaves was significantly affected by ringing. The highest significant carbohydrate content of leaves was obtained in girdled shrubs at April (Table 3). Also, the carbohydrate content in shoots at harvest time showed highly significant differences because of treatments. Removal of a strip of phloem from the main trunk by girdling actually blocks the transport of sugars to the roots; large amounts of carbohydrates produced by photosynthesis will accumulate in vegetative organs above the girdle or be used for fruit development. Girdling has been shown to increase the carbohydrate concentration above the girdle in Vitis vinifera L. (Roper \& Williams 1989).

Table 3. The effect of girdling on total carbohydrate content of barberry leaves and shoots (2017)

\begin{tabular}{lcc}
\hline \multirow{2}{*}{ Girdling date } & \multicolumn{2}{c}{ Tissue type } \\
\cline { 2 - 3 } & $\begin{array}{c}\text { leaves } \\
\left(\mathrm{mg} \cdot \mathrm{g}^{-1} \mathrm{DM}\right)\end{array}$ & $\begin{array}{c}\text { shoots } \\
\left(\mathrm{mg} \cdot \mathrm{g}^{-1} \mathrm{DM}\right)\end{array}$ \\
\hline Control & $25.6 \mathrm{a} \pm 0.9$ & $3.3 \mathrm{~b} \pm 0.6$ \\
April girdling & $43.9 \mathrm{a} \pm 1.2$ & $0.1 \mathrm{~b} \pm 0.6$ \\
September girdling & $14.9 \mathrm{~b} \pm 0.8$ & $49.4 \mathrm{a} \pm 2.1$ \\
\hline
\end{tabular}

Note see Table 2

There were significant differences between starch in the shoots $(0.212)$ and starch in leaves (0.226) (Table 4), but the interaction of treatment and tissue type on starch did not differ significantly compared to control (Table 5). Girdling affected the activity of key enzymes involved in carbohydrate metabolism of the growing apple and decreased the starch level (Berüter \& Feusi 1997). Li et al. (2003) reported that concentration of starch in girdled tree 
leaves was thrice that of control tree leaves and in girdled tree bark, it was twice that of control tree bark.

Table 4. The effect of girdling on starch of barberry (2017)

\begin{tabular}{ll}
\hline & Starch $(\mathrm{DM} \%)$ \\
\hline \multicolumn{1}{c}{ Girdling date } \\
\hline Control & $0.217 \mathrm{a} \pm 0.003$ \\
April girdling & $0.224 \mathrm{a} \pm 0.008$ \\
September girdling & $0.217 \mathrm{a} \pm 0.003$ \\
\hline \multicolumn{1}{c}{ Tissue type } & \\
\hline Leaves & $0.226 \mathrm{a} \pm 0.005$ \\
Shoots & $0.212 \mathrm{~b} \pm 0.0008$ \\
\hline
\end{tabular}

In each column means with the same letter are not significantly different at $5 \%$ level of probability using LSD.

Table 5. The effect of treatment and tissue type on starch in barberry (2017).

\begin{tabular}{lcl}
\hline \multicolumn{1}{c}{ Girdling date } & Tissue type & Starch $(\mathrm{DM}$ in $\%)$ \\
\hline \multirow{2}{*}{ Control } & Leaves & $0.223 \mathrm{a} \pm 0.006$ \\
& Shoots & $0.211 \mathrm{a} \pm 0.0007$ \\
\hline \multirow{2}{*}{ April girdling } & Leaves & $0.234 \mathrm{a} \pm 0.017$ \\
& Shoots & $0.215 \mathrm{a} \pm 0.002$ \\
\hline \multirow{2}{*}{ September girdling } & Leaves & $0.222 \mathrm{a} \pm 0.005$ \\
& Shoots & $0.212 \mathrm{a} \pm 0.001$ \\
\hline
\end{tabular}

Note see Table 1

\section{CONCLUSION}

However, the effect of girdling on plant is not clear but it has been proved that simple action such as ringing causes changes in fruit characteristic. So, it must be considered as an option for better management of orchards. According to our study, girdling in September resulted in a stronger effect on fruit quality of barberry plant. Hence, late girdling would be more beneficial for improving fruit quality.

\section{REFERENCES}

Arakawa O., Kanetsuka A., Kanno, K., Shiozaki Y. 1998. Effects of five methods of bark inversion and girdling on the tree growth and fruit quality of 'Megumi' apple. Journal of the Japanese Society for Horticultural Science, 67(5): 721-727. DOI: 10.2503/jjshs.67.721.

Arayne M.S., Sultana N., Bahadur S.S. 2007. The berberis story: Berberis vulgaris in therapeutics. Pakistan Journal of Pharmaceutical Sciences, 20(1): 83-92.
Berüter J., Feusi M.E.S. 1997. The effect of girdling on carbohydrate partitioning in the growing apple fruit. Journal of Plant Physiology, 151(3): 277-285. doi.org/10.1016/S0176-1617(97)80253-2.

Brar H.S., Singh Z., Swinny E., Cameron I. 2008. Girdling and grapevine leafroll associated viruses affect berry weight, color development and accumulation of anthocyanins in 'Crimson Seedless' grapes during maturation and ripening. Plant Science, 175(6): 885897. doi.org/10.1016/j.plantsci.2008.09.005.

Carreño J., Faraj S., Martinez A. 1998. Effects of girdling and covering mesh on ripening, color and fruit characteristics of 'Italia' grapes. The Journal of Horticultural Science and Biotechnology, 73(1): 103-106. DOI: 10.1080/14620316.1998.11510951.

Chevallier A. 2001. Encyclopedia of Medicinal Plants. St. Leonards. New South Wales, Australia: DK Publishing.

Choi S.T., Song W.-D., Park D.-S., \& Kang S.-M. 2010. Effect of different girdling dates on tree growth, fruit characteristics and reserve accumulation in a late-maturing persimmon. Scientia Horticulturae 126(2): 152-155. DOI: $10.1016 /$ j.scienta.2010.06.026.

Chuah A.M., Lee Y.-C., Yamaguchi T., Takamura H., Yin L.J., Matoba T. 2008. Effect of cooking on the antioxidant properties of coloured peppers. Food Chemistry. 111(1): 20-28. DOI: 10.1016/j.foodchem.2008.03.022.

Cochran R., Adams D., Wallace J., Galyean M. 1986. Predicting digestibility of different diets with internal markers: evaluation of four potential markers. Journal of Animal Science. 63(5): 1476-1483. DOI: $10.2527 /$ jas1986.6351476x

Davie S., Stassen P., Van der Walt M., Snijder B. 1995. Girdling avocado trees for improved production. South African Avocado Growers' Association Yearbook, 18: 51-53.

El-Hammady A., Abd-El-Hamid N. 1995. Effects of GA3, NAA and cane girdling on yield and quality of" King's Ruby" grapevines. Annals of Agricultural Science (Egypt).

Fatehi-Hassanabad Z., Jafarzadeh M., Tarhini A., Fatehi, M. 2005. The antihypertensive and vasodilator effects of aqueous extract from Berberis vulgaris fruit on hypertensive rats. Phytotherapy Research 19(3): 222-225. DOI: 10.1002/ptr.1661.

Goren R., Huberman M., Goldschmidt E. 2004. Girdling: physiological and horticultural aspects. Horticultural Reviews 30: 1-36. DOI: 10.1002/9780470650837.ch1. 
Janick J. 2003. Horticultural Reviews, Vol. 30. John Wiley \& Sons.

Khandaker M.M., Hossain A.S., Osman N., Boyce A.N. 2011. Application of girdling for improved fruit retention, yield and fruit quality in Syzygium samarangense under field conditions. International Journal of Agriculture and Biology 13(1): 18-24.

Kubota N., Nishiyama N., Shimamura K. 1993. Effects of girdling lateral bearing branches on astringency and phenolic contents of peach fruits. Journal of the Japanese Society for Horticultural Science 62(1): 69-73. DOI: 10.2503/jjshs.62.69.

Lee S.K., Kader A.A. 2000. Preharvest and postharvest factors influencing vitamin $\mathrm{C}$ content of horticultural crops. Postharvest Biology and Technology 20(3): 207-220. DOI: 10.1016/S0925-5214(00)00133-2.

Li C.Y., Weiss D., Goldschmidt E.E. 2003. Girdling affects carbohydrate-related gene expression in leaves, bark and roots of alternate-bearing citrus trees. Annals of Botany 92(1): 137-143. DOI: 10.1093/aob/mcg108.

Lichtenthaler H.K. 1987. [34] Chlorophylls and carotenoids: pigments of photosynthetic biomembranes. Methods in Enzymology 148: 350-382. DOI: 10.1016/0076-6879(87)48036-1.

Magel E. 1991. Qualitative and quantitative determination of starch by a colorimetric method. Starch-Stärke 43(10): 384-387. DOI: 10.1002/star.19910431003.

Martin T.A., Teskey R.O., Dougherty P.M. 1994. Movement of respiratory $\mathrm{CO}_{2}$ in stems of loblolly pine (Pinus taeda L.) seedlings. Tree Physiology 14(5): 481-495. DOI: 10.1093/treephys/14.5.481.

Mason T., Maskell E. 1928. Studies on the transport of carbohydrates in the cotton plant. I. A study of diurnal variation in the carbohydrates of leaf, bark, and wood, and of the effects of ringing. Annals of Botany 42(165): 189-253. DOI: 10.1093/oxfordjournals.aob.a090110.

Mocready R., Guggolz J., Silviera V., Owens H. 1950. Determination of starch and amylose in vegetables. Application to peas. Analytical Chemistry 22: 1156-1158. DOI: 10.1021/ac60045a016.

Mostafa E.A.M., Saleh M.M.S. 2006. Response of Balady mandarin trees to girdling and potassium sprays under sandy soil conditions. Research Journal of Agriculture and Biological Sciences 2: 137-141.

Noel A. 1970. The girdled tree. The Botanical Review 36(2): 162. DOI: 10.1007/BF02858959.

Nordgren A., Ottosson Löfvenius M., Högberg M., Mellander P.E., Högberg P. 2003. Tree root and soil heterotrophic respiration as revealed by girdling of boreal Scots pine forest: extending observations beyond the first year. Plant, Cell \& Environment 26(8): 12871296. DOI: 10.1046/j.1365-3040.2003.01053.x.

Priestley C. 1976. Some effects of ringing branches on the distribution of dry matter in young apple trees. Journal of Experimental Botany 27(6): 1313-1324. doi: 10.1093/jxb/27.6.1313.

Ranganna S. 1977. Manual of analysis of fruit and vegetable products.

Rivas F., Arbiza H., Gravina A. 2004. Caracterización del comportamiento reproductivo de la mandarina 'Nova' en el sur del Uruguay. Agrociencia 8(2): 79-88.

Rivas F., Fornes F., Agustí M. 2008. Girdling induces oxidative damage and triggers enzymatic and nonenzymatic antioxidative defences in Citrus leaves. Environmental and Experimental Botany 64(3): 256-263. DOI: 10.1016/j.envexpbot.2008.07.006.

Ronald E., Wrolstad P. 2001. The possible health benefits of anthocyanin pigments and polyphenolics. Department of food science and technology. Oregon State University. Corvallis, Oregon.

Roper T.R., Williams L.E. 1989. Net $\mathrm{CO}_{2}$ assimilation and carbohydrate partitioning of grapevine leaves in response to trunk girdling and gibberellic acid application. Plant Physiology 89(4): 1136-1140. DOI: $10.1104 / p p .89 .4 .1136$.

Schaper H., Chacko Csiro E. 1993. Effect of irradiance, leaf age, chlorophyll content and branch-girdling on gas exchange of cashew (Anacardium occidentale L.) leaves. Journal of Horticultural Science 68(4): 541-550. DOI: 10.1080/00221589.1993.11516383.

Sharif A.H., Fusao M., Onguso J.M., El-Shereif A.R., Hisashi Y. 2007. Inhibiting peach-tree growth with abscisic acid, hinokitiol and tropolone applied to partially ringed bark strips. The Journal of Horticultural Science and Biotechnology 82(2): 175178. DOI: $10.1080 / 14620316.2007 .11512216$.

Wagner G.J. 1979. Content and vacuole/extravacuole distribution of neutral sugars, free amino acids, and anthocyanin in protoplasts. Plant Physiology 64(1): 88-93. DOI: 10.1104/pp.64.1.88.

Williams L.E., Retzlaff W.A., Yang W., Biscay P.J., Ebisuda N. 2000. Effect of girdling on leaf gas exchange, water status, and non-structural carbohydrates of field-grown Vitis vinifera L.(cv. Flame Seedless). American Journal of Enology and Viticulture 51(1): 49-54.

Zhao Y., Zhang L., Gao M., Tian L., Zheng P., Wang K., et al. K. 2013. Influence of girdling and foliar-applied urea on apple (Malus domestica L.) fruit quality. Pakistan Journal of Botany 45: 1609-1615. 